\title{
Isolation and Characterization of Rice Bran Protein Using NaOH Solution
}

\author{
Akyunul Jannah \\ Jurusan Kimia, Fakultas Sains dan Teknologi, Universitas Islam Negeri Maulana Malik Ibrahim Malang \\ Email: akyunul_jannah2008@yahoo.com
}

\begin{abstract}
The high protein content in rice bran potential to be developed into food. The purpose of this study was to isolate the protein in rice bran using $\mathrm{NaOH}$ solution with various concentration of $0.05 ; 0.1 ; 0.15 ; 0.2 \mathrm{M}$ and characterization of functional properties. The results showed the concentration of $0.2 \mathrm{M} \mathrm{NaOH}$ produced the best results. The protein content obtained was $82 \%$, stability of emulsion of $42 \%$ and $47 \%$ stabilty of foam.
\end{abstract}

Keywords: $\mathrm{NaOH}$, protein, rice bran

\section{Abstrak}

Tingginya kandungan protein pada bekatul cukup potensial untuk dikembangkan menjadi bahan pangan. Tujuan dari penelitian ini untuk mengisolasi protein dalam bekatul dengan menggunakan larutan $\mathrm{NaOH}$ dengan variasi konsentrasi 0,$05 ; 0,1 ; 0,15 ; 0,2 \mathrm{M}$ dan karakterisasi sifat fungsionalnya. Hasil penelitian menunjukkan pada konsentrasi $0,2 \mathrm{M} \mathrm{NaOH}$ dihasilkan hasil yang terbaik. Kadar protein yang didapat adalah 82 $\%$, sedangkan untuk stabilitas emulsi sebesar $42 \%$ dan stabiltas buih $47 \%$.

Kata kunci: $\mathrm{NaOH}$, protein, bekatul

\section{PENDAHULUAN}

Bekatul mengandung 11,8-13,0 \% protein; $10,1-12,4 \%$ lemak; $2,3-3,2 \%$ serat kasar; 51,1-55,0 \% karbohidrat; 5,2-7,3 \% abu; dan 7,0-11,4\% serat kasar. Tingginya kandungan protein pada bekatul cukup potensial untuk dikembangkan menjadi bahan pangan. Komposisi protein dalam bekatul antara lain adalah $37 \%$ albumin, 36 $\%$ globulin, $22 \%$ glutelin, dan $5 \%$ prolamin (Wang, et al., 1999). Protein merupakan salah satu jenis zat penting yang sangat dibutuhkan oleh tubuh dengan sifatsifat fungsional dan gizi yang baik. Limbah bekatul bebas lemak merupakan sumber alternatif yang perlu dimanfaatkan selain sumber-sumber protein tradisional lain yang telah dikenal. Isolat protein bekatul mempunyai potensi untuk dikembangkan pemanfaatannya.

Faktor penting yang perlu diperhatikan dalam pemanfaatan protein sebagai produk pangan adalah sifat-sifat fungsionalnya karena sifat-sifat fungsional dapat mempengaruhi karakteristik produk pangan. Setiap sumber dan struktur protein meliliki sifat fungsional yang berbeda. Sifat-sifat fungsional protein dapat dianalisis sehingga dapat diketahui bagaimana karakteristik protein yang pada ahirnya dapat menentukan arah pemanfaatannya dalam proses pengolahan pangan. Untuk memperoleh protein bekatul, perlu dilakukan isolasi untuk mengetahui suatu protein mempunyai sifat-sifat kimia dan fisika yang baik dalam isolat protein. Isolasi protein dilakukan dengan variasi konsentrasi $\mathrm{NaOH}$. Penggunaan larutan $\mathrm{NaOH}$ karena dimungkinkan dalam keadaan basa kelarutan suatu protein bertambah besar, sehingga dilakukan proses ekstraksi menggunakan $\mathrm{NaOH}$ untuk memisahkan kandungan protein.

\section{METODE PENELITIAN 1. Preparasi Sampel}

Prosedur preparasi sampel adalah bekatul yang diperoleh hasil pengilingan 
diayak menggunakan ayakan 60 mesh, selanjutnya bekatul yang lolos ayakan dilakukan penghilangan lemak (delipid) bekatul. Ditimbang 20 gram sampel bekatul dalam kertas saring kemudian dimasukkan ke dalam tabung ektraksi soxhlet dalam thimble. Kemudian dimasukkan pelarut petroleum ether secukupnya dan dirangkai alat ektraksi soxhlet. Ekstrkasi dilakukan pada suhu $30 \quad$ ( \pm 3 kali siklus) sampai pelarut berwarna pucat. Kemudian dipisahkan sampel dari pelarut dan sampel dikeringkan dalam lemari asam. Selanjutnya sampel yang kering diisolasi.

\section{Isolasi Protein}

Protein bekatul dimaserasi dengan pelarut $\mathrm{NaOH}$ dalam perbandingan $1: 10 \mathrm{~b} / \mathrm{v}$ pada suhu ruang selam 2 jam dengan menggunakan shaker dengan variasi konsentrasi 0,$05 ; 0,1 ; 0,15 ; 0,2 \mathrm{M}$, selanjutnya disentrifuse untuk menghilangkan fraksi bekatul. Filtrat diendapkan dengan $\mathrm{HCl} 2 \mathrm{~N}$ sampai $\mathrm{pH}$ 4,5. Untuk memberi kesempatan pengendapan berlangsung dengan baik maka masa endapan dibiarkan selama lebih-kurang 12 jam pada suhu $4-5{ }^{\circ} \mathrm{C}$ (dalam almari pendingin). Selanjutnya endapan dipisahkan dengan cara disaring. Endapan protein yang diperoleh dikeringkan pada udara terbuka $\pm 24-30$ jam. Setelah kering isolat protein dihaluskan dengan mortar.

\section{Karakterisasi Protein Bekatul}

a. Penentuan Kadar Protein dengan Metode Kjeldahl

Sampel ditimbang sebanyak $1 \mathrm{~g}$ lalu dilarutkan bahan dengan aquades dengan volum tertentu (menentukan nilai faktor pengencerannya). Dimasukkan bahan ke dalam tabung kjeldahl, lalu ditambahkan 2 $\mathrm{ml} \mathrm{H}_{2} \mathrm{SO}_{4}$ pekat dan tambahkan 2 gram campuran $\mathrm{Na}_{2} \mathrm{SO}_{4}$ - $\mathrm{HgO}$ (20:1) untuk katalisator. Didihkan sampai jernih (kurang lebih 4 jam) dan lanjutkan pendidihan 30 menit lagi (pengerjaan harus dilakukan di lemari asam/fume hood). Setelah dingin ditambahkan $35 \mathrm{ml}$ aquades dan ditambahkan 8,5 ml NaOH- $\mathrm{Na}_{2} \mathrm{~S}_{2} \mathrm{O}_{3}$ dan dilakukan destilasi, destilat ditampung dalam $6,5 \mathrm{ml} \mathrm{H}_{3} \mathrm{BO}_{3} 4 \%$ yang telah diberi tetesan indikator metil merah dan ditampung sebanyak $25 \mathrm{ml}$. Dititrasi destilat yang diperoleh dengan $\mathrm{HCl} 0,02 \mathrm{~N}$ (b) sampai terjadi perubahan warna, dari kuning menjadi merah. Kadar protein dihitung menggunakan rumus:

$$
\text { Protein }(\%)=\frac{b \times c}{a \times 1000} \times 14,008 \times f p \times 6,25 \times 100 \%
$$

Keterangan:

$$
\begin{aligned}
& a: \text { berat sampel } \\
& b: \text { volume titran } \mathrm{HCl} \\
& \mathrm{c}: \mathrm{N} \text { titran } \mathrm{HCl} \\
& \mathrm{fp}: \text { faktor pengenceran }
\end{aligned}
$$

\section{b. Stabilitas Emulsi}

Sebanyak 0,5 gram sampel disuspensi dalam $5 \mathrm{ml}$ aquades setelah itu ditambahkan aquades sampai 7,5 $\mathrm{ml}$ dan minyak jagung sebanyak 7,5 ml, kemudian diblender selama \pm 2 menit. Hasilnya dituang dalam beaker gelas dan dipanaskan pada suhu $80 \mathrm{C}$ selama 30 menit. Air yang sudah tidak membentuk emulsi dipisakhan dan emulsi yang terbentuk kemudian ditimbang. Stabilitas emulsi dinyatakan sebagai campuran yang masih membentuk emulsi setelah mengalami pemanasan dan dihitung menggunakan rumus:

Stabilitas emulsi $=\frac{\text { berat fase tersisa }}{\text { berat total bahan emulsi }} \times 100 \%$

\section{c. Stabilitas Berbuih}

Sebanyak 0,5 gram sampel dilarutkan dalam $10 \mathrm{ml}$ aquades dan dihomogenkan dengan shaker selama \pm 1 menit. Larutan kemudian diatur pHnya hingga 8 dan dikocok selama 2 menit. Volume buih sebelum dan sesudah dikocok dicatat, 
kemudian kapasitas berbuih dinyatakan sebagai berikut:

Stabilitas berbuih $=\frac{\text { vol. buih terbentuk berat fase tersisa }}{\text { vol. cairan mula }- \text { mula }} \times 100 \%$

Untuk mengamati stabilitas buih selama waktu tertentu, emulsi yang sudah terbentuk disimpan selama beberapa lama pada suhu ruang. Volume buih diamati pada jam ke 0,$5 ; 1 ; 1,5 ; 2 ; 3 ; 4$ kemudian dicatat dan dibuat kurva kestabilan buih terhadap waktu.

\section{HASIL DAN PEMBAHASAN}

Sampel yang digunakan dalam penelitian ini adalah bekatul (rice bran) yang diperoleh dari daerah Malang yaitu berupa serbuk yang masih kasar. Preparasi bekatul dilakukan dengan cara pengayakan 60 mesh. Sampel yang telah diayak selanjutnya dilakukan proses penghilangan lemak (delipid) yang dilakukan dengan metode soxhletasi menggunakan pelarut petroleum eter. Adanya lemak dalam jumlah yang relatif tinggi akan menyulitkan dalam pemisahan protein karena lemak akan terdapat pada permukaan atas supernatan ekstrak protein. Semua ini perlu diperhatikan untuk memperoleh isolat dalam jumlah dan kadar protein yang tinggi. Hasil kadar lemak dalam bekatul diperoleh sebesar 7,336 \%. Selanjutnya bekatul bebas lemak akan diisolasi proteinnya dan dikarakterisasi sifat-sifat fungsionalnya.

\section{Isolasi Protein Bekatul}

Konsentrasi $\mathrm{NaOH}$ yang digunakan dalam isolasi bekatul adalah 0,$05 ; 0,1 ; 0,15$; 0,2 M. Penggunaan $\mathrm{NaOH}$ yaitu untuk memisahkan asam-asam amino dalam sampel yang biasa disebut sebagai proses hidrolisis. Pengendapan protein digunakan larutan $\mathrm{HCl} 2 \mathbf{3} \mid \mathrm{P}$ a g e $\mathrm{N}$ pH 4,5. Penggunaan larutan $\mathrm{HCl}$ umum digunakan dalam isolasi protein, selain itu juga $\mathrm{NaOH}$ dan $\mathrm{HCl}$ merupakan pereaksi yang sangat efektif dan ekonomis dalam isolasi protein.
Sedangkan pengggunaan $\mathrm{pH}$ 4,5 karena pada Rukmini (1988) telah melakukan pengendapan protein pada $\mathrm{NaOH}$ menggunakan $\mathrm{HCl}$ dengan variasi $\mathrm{pH}$, dan $\mathrm{pH}$ pengendapan yang maksimal adalah $\mathrm{pH}$ 4,5.Dengan demikian diharapkan larutan ini dapat menjamin diperolehnya protein bekatul dengan sifat-sifat fungsional yang lebih baik. Hasil Pengendapan protein disajikan dalam tabel 1 .

Tabel 1. Hasil Pengendapan Ekstrak $\mathrm{NaOH}$

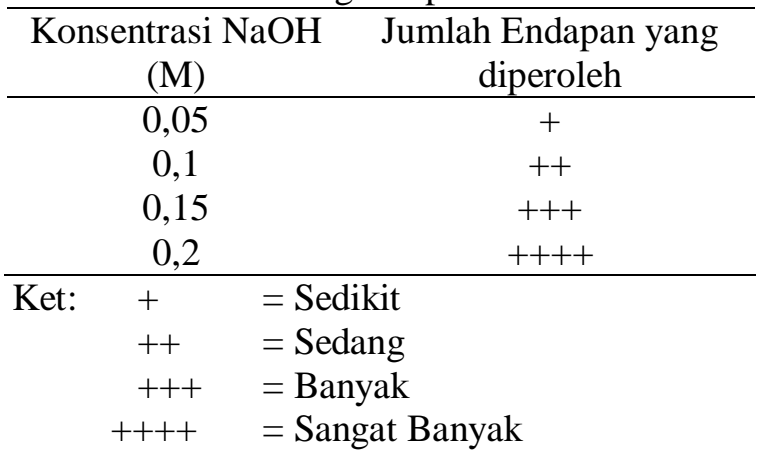

Karakterisasi Protein Bekatul

a. Penentuan kadar Protein dengan Metode Kjeldahl

Hasil analisis uji protein didapatkan kadar protein dalam bekatul ekstrak $\mathrm{NaOH}$ lebih besar seiring dengan meningkatnya konsentrasi $\mathrm{NaOH}$ yang digunakan. Melalui titrasi ini, dapat diketahui kandungan $\mathrm{N}$ dalam bentuk NH4 sehingga kandungan $\mathrm{N}$ dalam protein pada sampel bekatul dapat diketahui. Hasil kadar protein bekatul dengan variasi konsentrasi $\mathrm{NaOH}$ adalah pada Tabel 2.

Tabel 2. Hasil Kadar Protein Analisis Kjeldahl

\begin{tabular}{cc}
\hline $\begin{array}{c}\text { Konsentrasi NaOH } \\
(\mathbf{M})\end{array}$ & $\begin{array}{c}\text { Kadar Protein } \\
(\boldsymbol{\%})\end{array}$ \\
\hline 0,05 & 74,630 \\
0,10 & 77,374 \\
0,15 & 81,391 \\
0,20 & 82,131 \\
\hline
\end{tabular}

Kadar protein bekatul yang diekstrak dengan larutan $\mathrm{NaOH}$ 0,2 M lebih besar daripada konsentrasi yang lebih rendah. Hal ini menunjukan bahwa kelarutan protein 
dalam pelarut dapat meningkat dengan penambahan konsentrasi $\mathrm{NaOH}$. Bera dan Mukherjee (1989) melaporkan bahwa kadar protein bekatul hasil dari isolasi yang didapatkan adalah $90 \%$.

\section{b. Stabilitas Emulsi}

Emulsi merupakan suatu dispersi atau suspensi suatu cairan dalam cairan yang lain, yang mana molekul-molekul kedua cairan tidak saling berbaur tetapi saling antagonistik. Protein bekatul mempunyai stabilitas emulsi yang semakin baik berdasarkan peningkatan konsentrasi yang digunakan, sehingga dapat dijadikan sebagai sumber alternatif untuk bahan pangan yang membutuhkan stabilitas emulsi seperti pembuatan mayoninnaise dan susu. Grafik stabilitas emulsi ekstrak $\mathrm{NaOH}$ dilihat pada Gambar 3.

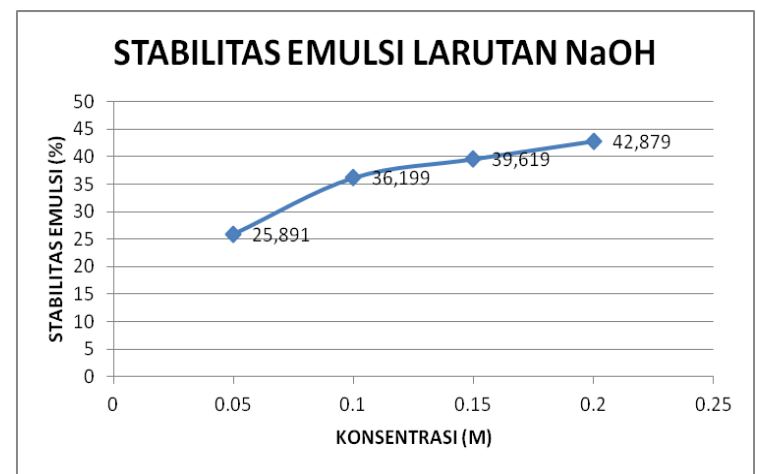

Gambar 3. Grafik rata-rata nilai stabilitas emulsi ekstrak $\mathrm{NaOH}$

Nilai stabilitas emulsi tertinggi pada konsentrasi $0,2 \mathrm{M}$ yakni $42,879 \%$. Nilai stabilitas emulsi protein bekatul dalam penelitian ini masih berada dibawah nilai stabilitas emulsi pada penelitian yang dilakukan oleh Mukherjee (1989) terhadap protein bekatul yakni sebesar $74 \%$. Perbedaan ini dimungkinkan karena sampel bekatul yang digunakan didapatkan dari tempat yang berbeda. Semakin tinggi stabilitas emulsi maka semakain tinggi pula sifat fungsional protein tersebut, sehingga dapat dimungkinkan digunakan sebagai bahan produk pangan.

\section{c. Sifat Buih}

Buih merupakan dispersi koloid dari fase gas dalam fase cair, yang dapat terbentuk saat dikocok. Selama pengocokan akan terjadi peningkatan dan penurunan ukuran dan jumlah gelembung udara. Daya buih merupakan ukuran kemampuan protein bekatul untuk membentuk buih jika dikocok, sedangkan stabilitas buih merupakan ukuran kemampuan struktur buih putih telur untuk bertahan kokoh atau tidak mencair selama waktu tertentu. Data tabel dapat dilihat pada lampiran 4. Grafik kestabilan buih ekstrak $\mathrm{NaOH}$ dapat dilihat pada Gambar 4.

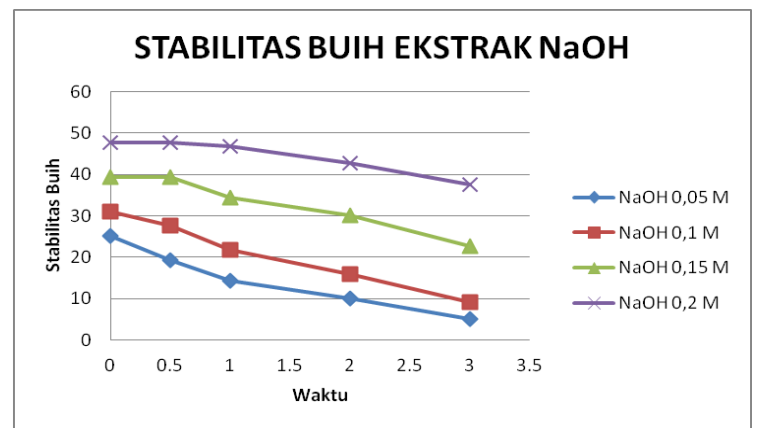

Gambar 4 Grafik rata-rata nilai stabilitas buih ekstrak $\mathrm{NaOH}$

Berdasarkan Gambar 4 diketahui bahwa nilai stabilitas buih protein bekatul ekstrak larutan $\mathrm{NaOH}$ semakin tinggi konsentrasi yang digunakan maka semakin tinggi kestabilan buihnya. Salah satu faktor yang mempengaruhi kestabilan buih adalah viskositas. Powrie dan Tung (1976) mengemukakan bahwa stabilitas buih dapat ditingkatkan dengan meningkatkan viskositas larutan, sedangkan viskositas akan semakin tinggi dengan tingginya konsentrasi protein. Buih dapat stabil apabila viskositas semakin tinggi. 


\section{KESIMPULAN}

Berdasarkan hasil penelitian yang didapatkan, maka dapat disimpulkan bahwa pada variasi konsentrasi larutan $\mathrm{NaOH}$ untuk isolasi protein bekatul didapatkan konsentrasi terbaik adalah 0,2 $\mathrm{M}$ baik dari hasil kadar protein maupun sifat-sifat fungsional protein. Kadar protein yang didapat adalah $82 \%$, sedangkan untuk stabilitas emulsi sebesar $42 \%$ dan stabiltas buih pda ekstrak $\mathrm{NaOH} 0,2 \mathrm{M}$ memiliki stabilitas yang terbaik dari pada konsentrasi yang lain.

\section{DAFTAR PUSTAKA}

M.B.Bera \& R.K. Mukherjee. 1989. Solubility, Emulsifying and Foaming Properties of Rice Bran
Protein Concentrate. J. Food Sci., Vol. 54 (1): 142-145

Powrie, W.D. \& Tung, M.A. 1976. Food Dispersions, In Principle of Food Science, Part 1, Food chemistry, Fennema OR. Marcel Dekker, Inc, New York.

Rukmini, H. S. 1988. Perbaikan sifat-sifat Fungsional Protein Dedak Padi Secara Kimiawi. Tesis Tidak Diterbitkan. Bogor: ITB

Wang, M., Hettiarachchy, N. S., Qi, Burks, M. W., dan Siebenmorgen, T. 1999. Preparation and Functional Properties of Rice Bran Protein Isolate. J Food Chem, Vol. 47: 411416. 